\title{
Phytochemical Investigation of Gagea Reticulate (Kuwait Medicinal Plants)
}

\author{
HADI A. AL-NAJJAR, Ph.D. \\ The Department of Public Authority for Applied Education and Training Pharmacy, College of Health Sciences, \\ (PAAET), Kuwait
}

\begin{abstract}
Background: Gagea reticulate is one of the medicinal plants, yet there is no enough information about its phytochemical profile. In this endeavour.

Aim of Study: This study was aimed to carry out a detailed phytochemical screening of the active constituents in the bulbs, stems, leaves and flowers of Gagea reticulate growing wildly in Kuwait.

Material and Methods: Phytochemical screening were done for plant after collection of flowering plants from Kabd area of Kuwait during the spring of 2005.

Results: The present study results reported the presence of high amounts of cardiac glycosides, Carbohydrates, flavonoids and steroids and triterperes in the bulbs while flavonoids is more abundant in the yellow flowers and the scarce presence of alkalonids.

Conclusion: Gagea reticulate plant contains significant amounts of cardiac glycosides, flavonoids and some sterols in the different parts of the plant especially the bulbs. The literature revealed similar findings in different species of the family. The results of the current paper could serve as a starting point for further future investigation of the contents of the Gagea reticulate plant.
\end{abstract}

Key Words: Gagea - Star-Glycosides - Flavanoids.

\section{Introduction}

GAGEA reticulata (Pall.) Schult. et Schult. f. (Liliaceae) is a yellow-flowereddwarf lily which is usually found on rocky terrain. It was listed as a plant (presumably the bulb) which can be consumed raw but, many consultants reported that it can not be eaten as the bulb is bitter. Although its common presense, the economic botanist Carter revealed that this species collected in the Kuwait hinterland is not used by men and also animals do not graze on it [1].

Correspondence to: Dr. Hadi A. Al-Najjar, E-Mail: ha.alnajiar@paaet.edu.kw
The Gageareticulata (Pall.) Schult. and Schult. f. species complex belongs to Gagea section Platyspermum and reported at least twelve named taxa with the names of, G. alexeenkoana Miscz., G. anonyma Rech.f., G. bergii Litv., G. calcicolaZarrei and Wilkin, G. caroli-kochii Grossh., G. commutate K. Koch, G. graminifolia Vved., G. reticulata, G. robusta Zarrei \& Wilkin, G. tenuifolia (Boiss.) Fomin, G. setifolia Baker, and G. vegeta Vved [2-5].

The main center for Gagea section Platyspermum diversity is reported in Iran, However most species are also growing in the neighboring countries. Many of them distribute widely till reaching as far as North Africa. G. reticulata is the most common widespread species in dry areas $[4,5]$.

With its bright yellow star shaped flower (Fig. 1) growing in higher grounds in Kuwait desert, and sometimes in the soft sandy sea shores, blooming very early in the spring, Gagea reticulate is considered to be one of the most beautiful rare flowers of Kuwait [6].

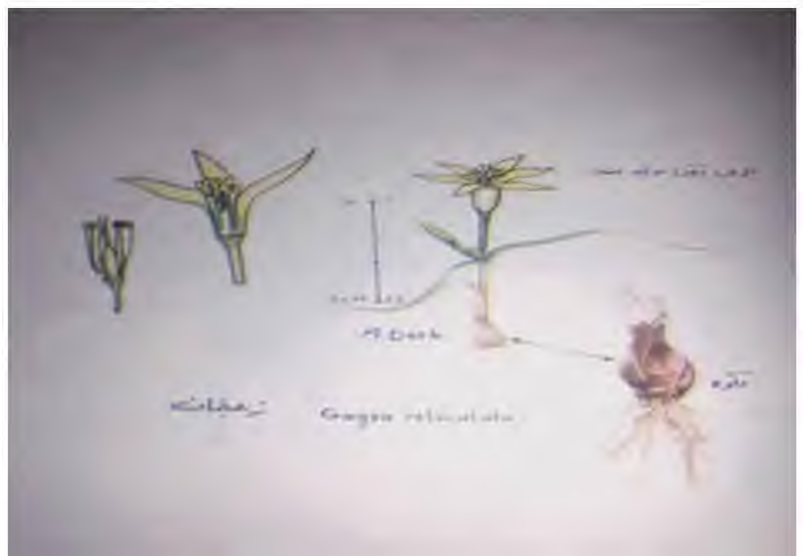

Fig. (1): Gagea Reticulata. 
In this investigation, preliminary phytochemical screening of the bulbs, stems, leaves and flowers of Gageareticulata is carried out with a detailed background literature survey for the hope of establishing a base for future more elaborate investigation.

\section{Experimental:}

\section{Plant material preparation:}

The whole plant of Gages reticulata was collected during the month of March which represents the end of spring season where the plants are in full blossoms just before the hot summer burned the delicate flower petals.

The plants are dried in shade and after performing macro-and micro-morphology they were powdered mechanically and sieved through a bomber 40 sieve and saved in labeled containers for further investigations.

Photochemical screening investigation were carried out using procedure described by my previous instructors Brain and Turner [7].

Tests for after the different extractions specific reagents like Dragendorff's, Mayor's, Baljet, killer Kiliani, Froth tests and others were performed on aliquots of the different extracts of leaves stems bulbs and flowers of the plant.

\section{Plant material:}

Flowering plants were collected from Kabd area of Kuwait during the spring of 2005. A voucher specimen was deposited at Kuwait University herbarium after authentication by Dr. K.T. Mathew, Keeper of the herbarium.

\section{Phytochemical screening:}

Carried out according to standard procedures used by my former instructors Brian \& Turner [7].

\section{Results}

\section{Macro-morphology:}

Small buld with many roots inclosed in articulate fibrous coat with solitary leaves long and recurved exceeding the inflorescence; Scape short, bearing \pm umbelli form leapy cymes or corgumbs of flowers; perianth-segments pubescent, longacute about $8 \mathrm{~mm}$ long, $2-3 \mathrm{~mm}$ wide, outer ones logner than the inner, many-nerved, yellow with greenish-brown backs. Pedicels unequal, about $2 \mathrm{~cm}$ long, capsule oblong, about $1 \mathrm{~cm}$ long. With flat, angular seeds.

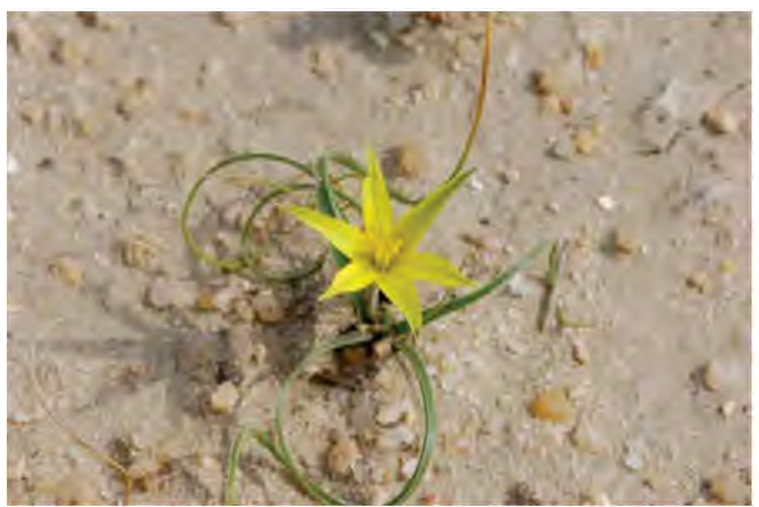

Fig. (2): Gagea Reticulata Flower.

Table (1): Phytochemical screening of gageareticulate.

\begin{tabular}{|c|c|c|}
\hline Test For & $\begin{array}{l}\text { Bulb \& } \\
\text { Stem }\end{array}$ & Leaf Flower \\
\hline $\begin{array}{l}\text { Sterols \& triterpenes: } \\
\text { Libermans Test } \\
\text { Slkwiski Test }\end{array}$ & ++ ve & $+\mathrm{ve}+\mathrm{ve}$ \\
\hline $\begin{array}{l}\text { Alkaloids or nitrogenus bases: } \\
\text { Dragenorffs reagent } \\
\text { Wagner's reagent } \\
\text { Mayer's reagent }\end{array}$ & $\begin{array}{l}+ \text { ve } \\
+ \text { ve } \\
+ \text { ve }\end{array}$ & $\begin{array}{l}-\mathrm{ve}-\mathrm{ve} \\
-\mathrm{ve}-\mathrm{ve} \\
-\mathrm{ve}-\mathrm{ve}\end{array}$ \\
\hline $\begin{array}{l}\text { Cardiac glycosides: } \\
\text { Keller Killiani Test } \\
\text { Baljet reaction }\end{array}$ & $\begin{array}{l}+++\mathrm{ve} \\
+++\mathrm{ve}\end{array}$ & $\begin{array}{l}+\mathrm{ve}+\mathrm{ve} \\
+\mathrm{ve}+\mathrm{ve}\end{array}$ \\
\hline $\begin{array}{l}\text { Flavonoids: } \\
\qquad \begin{array}{l}\text { NAOH Test } \\
\text { NH4OH Test } \\
\text { Alcl3/UV }\end{array}\end{array}$ & $\begin{array}{l}++\mathrm{ve} \\
++\mathrm{ve} \\
++\mathrm{ve}\end{array}$ & $\begin{array}{r}+\mathrm{ve}++ \text { ve } \\
+++\mathrm{ve} \\
+++\mathrm{ve}\end{array}$ \\
\hline $\begin{array}{l}\text { Anthraquinones: } \\
\text { Borntragers test }\end{array}$ & + ve & - ve - ve \\
\hline $\begin{array}{l}\text { Tannins: } \\
\text { FeCl3 test }\end{array}$ & $-\mathrm{ve}$ & - ve - ve \\
\hline $\begin{array}{l}\text { Saponins: } \\
\text { Forth test }\end{array}$ & ++ ve & $+\mathrm{ve}+\mathrm{ve}$ \\
\hline $\begin{array}{c}\text { Carbohydrates: } \\
\text { Molish test }\end{array}$ & $+++\mathrm{vc}$ & $+\mathrm{ve}-\mathrm{ve}$ \\
\hline
\end{tabular}

++ ve Slight, ++ ve Moderate, +++ ve High $\&$ - ve Negative.

\section{Discussion}

Gagea reticulate belongs to the liliacea family that is formed of at least 280 genera and 4000 species, mainly pereinal herbs of starchy rhizomes or corms. Most common names in this group of herbs are: Colchicum (65 spp.); Aloe (330 spp.); Gagea (70 spp.); Allium (450 spp.); Lilium (20 spp.); Tulipa (100 spp.); Scilla (80 spp.); Dipcadi, Asparagus, convallaria, agavaceae and smilax. Many members of the family are cultivated for their flowers, vegetables including asparagus, onion, garlic, shallot, leek and chives. Drugs including squill, Sarsaparilla, veratrum, colchicum and aloes [8]. 
Zarrei et al. (2009) examined species delimitation within Gagea and did not have enough character polymorphisms to uncover relationships between the five major groups [9].

Moreover, no resolution was observed between species in G. section Platyspermum Boiss., including the G. reticulatacomplex of species examined at that study. Although, its normally high level of evolutionary divergence, unequivocal evidence of relationships between major groups was not provided [10].

A designed study of morphological, karyological, and molecular evidence, it was reported that polyploidization and hybridization are responsible of Gagea evolution and speciation [11,12].

Zarrei et al. (2009) reported monophyly of the G. reticulata species complex and that there was no evidence of multiple copies of the Nuclear ribosomal internal transcribed spacer region with complete homogenization in the G. reticulata species complex [9].

Without providing resolution between the different complex species, Zarrei et al., 2012 explains that kind of pattern as most of the named taxa are closely related due to evolution/hybridization of reticulate in other groups [10].

However, genetic data for G. section Platyspermum and particularly the G. reticulata species complex are very scarce. Probably some taxa only merit recognition as subspecies or morphological variants. Zarrei et al. (2007, 2010b,c) have designed many studies for establishing species limits and published morphological details of Gagea species in Iran, giving a spot on the G. reticulata complex, but unfortunately that group suffers from a lack of detailed phylogenetic studies. Also, scarce karyological data about species of G. reticulata complex are available $[4,5,13]$.

Several gerera of this family are reputed for their folkloric use and active constituents [14]. Alkaloids as in colchicine [15], anthra quinines as in Aloe, Bulbina and other species [16,17], steroidal substances such as sterols, cardinolids, bufadienolides and steroidal saponins. The aminoacid azetidin-2-carboxylic acid in aganacea, other constituents such as anothocyanins and flavonoids, ypyronechelidonic acid; cyanogentic substances [8].

More than 20 cardioactive glycosides including convalltoxin, one of the strongest cardiotonics of vegetable world and convallotoxol and convallosid were reported in "Lily of the valley" Convallariamajalis [18].
Zargary [19] mentioned that in fusions of C. majalis in small doses could be used for strengthening heart muscles and as a diuretic.

A review by komiasarenko and stupakova [20] revealed cordiotonics, flavonoids and steroids isolated and synthesized from the genus Convallaria. In a different study by Evdokimove et al., [21], it was proven that cardinolides were more stable in extracts than in fusions in hot climates. Tittel [22] used improved HPLC techniques for the detiction of biological values of cardiac glycosides in convallaria herb. Strophanthidan is a product of the hydrolysis of convallatoxin, a number of flavonoid glycosides along with a saponinconvallamarozide were reported by shank [23] Convallaria Keiski (Japanese lily of the valley) contains glycosides of convallagenin. The dried roots of Adonis vernalis contains cumarim and strophanthus like glycosides. Squill which consist of the dried sliced bulbs of Drimiamaritina (Liliaceae) is the source of scillaren A, B Glycosides [8].

From what was mentioned above in Table (1) one can notice the presence of high amounts of cardiac glycosides, Carbohydrates, flavonoids and steroids and triterperes in the bulbs while flavonoids is more abundant in the yellow flowers and the scarce presence of alkalonids.

\section{Conclusion:}

From the literature survey and the phytocheimcalScreening tests, one could conclude that this plant contains significant amounts of cardiac glycosides, flavonoids and some sterols in the different parts of the plant especially the bulbs. The literature revealed similar findings in different species of the family. This report could very well serve as a starting point for further sophisticated analysis using GC/MS for the identification of the cardiotonics and flavonoids.

\section{References}

1- MANDAVILLE J.: Bedouin Ethnobotany: Plant Concepts and Plant Use in a Desert Pastoral WorldDoctor of Philosophy, Graduate College, University of Arizona, p. 155, 2004.

2- ZARREI M. and ZARRE S.: Pollen morphology of the genus Gagea (Liliaceae) in Iran. Flora, 200: 96-108, 2005.

3- ZARREI M., WILKIN P., INGROUILLE M.J., ZARRE S. and CHASE M.W.: The systematic importance of anatomical data in Gagea (Liliaceae) from Flora Iranica area. Bot. J. Linn. Soc., 164: 155-177, 2010a.

4- ZARREI M., WILKIN P., INGROUILLE M.J. and CHASE M.W.: Gageacalcicola (Liliaceae), a new species from southwestern Iran. Kew Bull, 65: 89-96, 2010 b. 
5- ZARREI M., WILKIN P., INGROUILLE M.J. and CHASE M.W.: Gagearobusta (Liliaceae), a new species from Flora Iranica area. Kew Bull, 65: 327-336, 2010c.

6- DEEB M. and ALSALEM K.: Wild plants of Kuwait Aljallal publications, Kuwait, 1974.

7- BRAIN K. and TURNER T.D.: The practical evaluation of phytophrmceuticals. Bristol., 1975.

8- TREASE G.E. and EVANS W.C.: Pharmacognosy $12^{\text {th }}$ ed Bailliere Tindall. London, 1983.

9- ZARREI M., WILKIN P., FAY M.F., INGROUILLE M.J., ZARRE S. and CHASE M.W.: Molecular systematics of Gagea and Lloydia (Liliaceae; Liliales): Implications of analyses of nuclear ribosomal and plastid sequences for infrageneric classification. Ann. Bot., 104: 125-142, 2009.

10- ZARREI M., WILKIN P., INGROUILLE M.J., LEITCH I.J., BUERKI S., FAY M.F., et al.: Speciation and evolution in the Gageareticulata species complex (Tulipeae; Liliaceae). Molecular Phylogenetics and Evolution, 62: 624-639, 2012.

11- PERUZZI L.: Hybridity as a main evolutionary force in the genus Gagea Salisb. (Liliaceae). Plants Biosyst, 142: 179-184, 2008

12- PETERSON A., HARPKE D., PERUZZI L., LEVICHEV I.G., TISON J.-M. and PETERSON J.: Hybridization drives speciation in Gagea (Liliaceae). Plant Evol., 278: 133-148, 2009.

13- ZARREI M., ZARRE S., WILKIN P. and RIX E.M.:
Systematic revision of the genus Gagea Salisb. (Liliaceae) in Iran. Bot. J. Linn. Soc., 154: 559-588, 2007.

14- WATT J.M. and BERYER BRANDWIIK M.G.: The medicinal and poisonous plants of southern and Eastern Africa, $2^{\text {nd }}$ ed. E\&S Leving stone Ltd. London, 1962.

15- GUNNER A.: Resimli Turkiye Floras (Illustrated Flora of Turkey). Ang Val/Nezahat Gokyi Botanik Bachcesi, Istanbul, 2: 1-1054, 2006.

16- ZARREI M., WIKIN P. and CHASE M.W.: Gageasalisb (Lilliacea) in Iran: An update species checklist phytotaxa, 15: 33-43, 2011.

17- LEVICHER I.G.: A review of the Gagea (Lileacea) Species in the flora of Caucasus. Botanicheski, Zhumal. Moscow @Liningrad, 91: 917-951, 2006.

18- SINGH N.P. and SANJAPPA M.: Flora of India. Botanical survey of India, New Delhi, 23: 1-134, 2006.

19- CHUDHARY S.A.: Flora of the kingdom of Saudi Arabia. Ministry of Agriculture \& Water Riyadh, 3: 1-368, 2001.

20- KOMIASSARENKO N.F. and STUPAKOVA E.P.: Rastet. Resur, 25 (3): 253-68 (Russ), 1989.

21- EVDOKIMOVE P.K., KHALAMATOV K.K. \& MOKHAMIDOVA M.: Ed. Zh. Uzb., 8: 64-66 (Russ.), 1991.

22- TITLE D.: Glycosides, 1785-1985: 315-321 London, 1986.

23- SHENK P.E.: Planta Med., 40: 1, 1980.

\title{
فحص نباتى كيميائى لنبات Gagea Reticulate (نباتات الكويت الطبية)
}

\author{
نبات Gagea reticulate هو واحد من النباتات الطبية ومـ ذلك لا توجل معلومات كافية حول ملفه الكيميائى. \\ الهدف من الدراسة وخطة البحث: تم تصميم هذه الدراسة لإجراء فحص كيميائى مفصل للمكونات الفعالة فى الأوداق والزهور لنبات

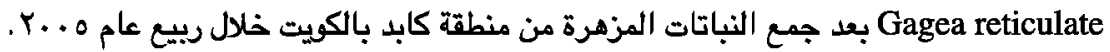 \\ نتائج البحث: أشارت نتائج الدراسة الحالية إلى وجود كميات كبيرة من الجليكوسيداتو الكربوهيدرات والفلافونويدات في حين الفلافونويدات

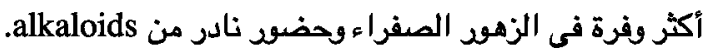

الخلاصدة: توجد كميات كبيرة من الجليكوبيدات والفلافونويدات وبعض الستيربل في الأجزاء المختلفة لنبات Gagea reticulate وكشفت

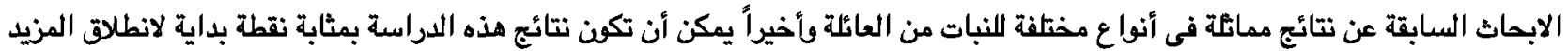

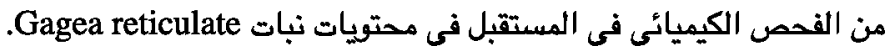

